\title{
Altägyptische Kalenderstudien
}

von

August Faselius.

STRASSBURG.

K A R L J. TRÜ B N ER.

LONDON.

TR Ü B NER \& CO.

1873. 
Bucbdruckerei von $(\mathrm{t}$. Ot $\mathrm{t} \Omega$ in Darmstadt. 


\section{Herrn \\ Dr. Johannes Diimichen \\ Professor an der Kaiserlichen Universität Strassburg}

iı dankbarer Verehrung

der Verfasser, 
